\title{
Brand types applied by emerging markets' firms: Country of brand origin and brand use motives
}

\author{
Marzanna K. Witek-Hajduk, Anna Grudecka
}

\begin{abstract}
A B S T R A C T
Objective: The objective of the article is to explore the types of brands in terms of the country of brand origin (COBO) applied by emerging markets' firms and motives for applying them.

Research Design \& Methods: A qualitative approach was used, i.e. multi-case study of five emerging markets' firms and data triangulation.

Findings: Studied firms apply in the international market various types of brands in terms of the COBO by 1 ) referring to the foreign $\mathrm{COBO}, 2$ ) referring to the origin from the home market, and 3) neutralising the $\mathrm{COBO}$ effect. Moreover, the firms differ in terms of their international brand portfolio: from consisting of a single brand to covering several or dozen international - even global - regional, or local brands.

Implications \& Recommendations: The dominant international branding strategy of emerging markets ‘ firms in terms of the СОВО is acquiring/ licensing well-known international or even global brand/ brands and creating 'occidental-style' brand. It is driven both by strategic and market motives. The conclusions can be applied by emerging markets' companies in their foreign expansion.
\end{abstract}

Contribution \& Value Added: This study develops a deeper understanding of the brand types applied by emerging markets' companies in terms of the COBO and brand use motives.

\begin{tabular}{|c|c|}
\hline $\begin{array}{l}\text { Article type: } \\
\text { Keywords: }\end{array}$ & $\begin{array}{l}\text { research article } \\
\text { international branding; the country of brand origin; COBO; emerging markets' firms' } \\
\text { strategies }\end{array}$ \\
\hline JEL codes: & M16, M31, F23 \\
\hline Receiv & Accepted: 22 September 2020 \\
\hline
\end{tabular}

\section{Suggested citation:}

Witek-Hajduk, M.K., \& Grudecka, A. (2021). Brand types applied by emerging markets' firms: Country of brand origin and brand use motives. Entrepreneurial Business and Economics Review, 9(1), 155-168. https://doi.org/10.15678/EBER.2021.090110

\section{INTRODUCTION}

In recent years, an increasing internationalisation and a growing significance of international branding of emerging markets' firms have been noticed (Erdoğmus, Bodur, \& Yilmaz 2010; Kazlauskaitė, Autio, Šarapovas, Abramavičius, \& Gelbūda, 2015). Multinational corporations from these countries play an increasingly important role in the global market (McKinsey Global Institute, 2018). For many years, emerging countries' firms had been operating in foreign markets primarily as suppliers of low-cost products or large multinational corporations' subcontractors (Guzmàn \& Paswan, 2009). Today, these companies compete both in emerging and developed countries based not only on cost advantage and lower prices but also on the uniqueness of products and application of strong brands (Pillania, 2009). International branding strategies of emerging markets' companies evolve as the degree of their internationalisation increases, starting with domestic branding through exporting products under Original Equipment Manufacturer (OEM) contracts and exporting products branded with own brands and under OEM contracts to international and global branding (Fan, 2008).

The negative impact of the country of brand origin (COBO) is one of the key barriers to foreign expansion of emerging markets' firms and brands (Chao, Samiee, \& Yip, 2004; Karimov \& El-Murad, 
2018). Consumers perceive products and brands from developed countries as better than those from emerging markets (Josiassen \& Harzing, 2008), which is reflected in customers' behaviour (Thakor \& Lavack, 2003). Negative associations with the СОВO reduce confidence in these brands and, as a result, consumers do not want to pay higher prices for them (Magnusson, Haas, \& Zhao, 2008), although 'more sophisticated consumers are more willing to buy the developing country brand origin than technologically less sophisticated consumers' (Lee, 2019). However, as moving through the next stages of internationalisation, the equity of brands managed by emerging markets' firms increases, and the negative impact of the СОВО becomes less significant (Fan, 2008). When developing a portfolio of brands applied internationally - wary of negative stereotypes (Chu, Chen, Chang, \& Wang, 2010; Kim, Chun, $\&$ Ko, 2017) - firms from emerging markets face a dilemma whether to allow for the COBO to be identified (Ille \& Chailan, 2011).

Although researchers underline the need to study the СОВО phenomenon from a strategic perspective (e.g. Hynes, Caemmerer, Martin, \& Masters, 2014), little research concerns the brand types used by emerging markets' firms in response to the СОВO effect and motives for applying them. Moreover, these studies are focused on brands from developed countries and Asian companies, mainly Chinese (e.g. Xie \& Boggs, 2006).

In view of the identified research gap, the aim of this article is to explore the types of brands in terms of the СОВО applied by emerging markets' firms and motives for applying them, answering research questions:

1. What types of brands are applied in foreign markets by companies from emerging countries in terms of the COBO?

2. What are the motives for applying these types of brands?

To answer these questions, a multi-case study of five emerging markets' companies and triangulation of both primary and secondary sources was applied.

Answering these questions broadens the knowledge on approaches to brand portfolio creation and brand types applied in the international market by companies from various emerging countries in terms of СОВО and brand use motives.

This paper is organised as follows. First, the literature pertinent to the international branding of emerging markets' firms in terms of the COBO is summarised. Next, the study method is outlined to be followed by a presentation of research findings. The paper concludes with a discussion of outcomes, limitations, and suggestions for further studies.

\section{LITERATURE REVIEW}

Our study refers to the country-of-origin paradigm, the signalling theory, and the brand origin recognition accuracy concept.

Since the 1960s, the country of origin (COO) has been one of the most important paradigms in the international marketing research. $\mathrm{COO}$ was initially understood as the country of manufacturing (COM; Nagashima, 1970). However, many researchers emphasis the COM's multidimensional character (e.g. Aruan, Crouch, \& Quester, 2018; Coffey \& Kabadayi, 2020) and indicate other dimensions, such as the country of design (COD; Insch \& McBride, 1998), the country of assembly (COA; Insch \& McBride, 1998), the country of parts (COP; Han \& Terpstra, 1988), the country of corporate ownership (COCO; Ozsomer \& Cavusgil, 1991), and - finally - the COBO (Thakor \& Kohli, 1996, p. 28) defined as 'the country to which the brand is perceived to belong.' Due to the changes in the global economy -including supply chains - some scholars postulate using the COBO construct (Thakor \& Lavack, 2003; Brodie \& Benson-Rea, 2016).

According to the signalling theory - based on the prerequisite of a rational and risk-averse individual - both the sender (firm) and the receiver (customer) of signals have an interest in reducing information asymmetry. From this perspective, a brand applied by the company from emerging market may be treated as a signal for reducing consumer uncertainty about the quality of a product (e.g. Erdem, 
Swait, \& Valenzuela, 2006), while the consumer as the receiver of this signal engages in the cognitive effort of its interpreting to limit uncertainty (e.g. Kirmani \& Rao, 2000).

When choosing the brands applied in the international market, firms may directly or indirectly refer to the positive image of the COBO (Aichner, 2014; Hynes, Caemmerer, Martin, \& Masters, 2014) or neutralise (hide, suppress) the poor image of the country from which brand originates (e.g. Herstein, Berger, \& Jaffe, 2014).

As Huang and Hsieh (2011) emphasise, emerging markets' firms face a key dilemma for the effectiveness of their international branding strategy: whether to refer to the Western culture or to the culture from which the company/brand originates. According to the studies on the brand origin recognition accuracy (BORA), consumer's recognition of a COBO is based on the associations of a brand name with the language of a given country (Samiee, Shimp, \& Sharma, 2005). By using brand name suggesting an origin from the country with a desired image (e.g. a Western brand name), firms may reduce the bias caused by the negative effect of the $\mathrm{COBO}$ and increase the effectiveness of their international strategy (Kim, 2006; Herstein, Berger, \& Jaffe, 2014). Emerging markets' firms may not only create new 'Western-style' international brands, which takes time, but also acquire an already existing well-known international brand (Huang \& Hsieh, 2011).

When developing a portfolio of brands and deciding whether to refer to the brand origin from a home market, emerging markets' firms should consider both the influence of the COBO on foreign customers' perception of trust vs risk generated by a brand and a global vs local approach to the brand image creation (IIle \& Chailan, 2011).

Considering the consumer's risk aversion towards a brand and the local vs global emphasis, Chailan and Ille (2015) indicate four options of brands that may be applied by the emerging markets' firms:

1. a well-known international, even global, brand acquired in order to reduce the customers' perceived risk by referring to the brand's global qualities,

2. an occidental-style brand created ex nihilo and introduced to foreign markets, conjuring up positive images among customers,

3. a brand already existing in the home country, emphasising its localness and referring to the positive image of the genuine COBO to reduce consumers' perception of risk, and

4. a new 'local-go-global' brand referring to the local language and cultural values.

Given the above, we propose:

H1: Companies from emerging countries apply on the foreign markets both brands referring to the brand origin from the foreign country with the positive image and brands referring to the positive image of the home country.

H2: The choice of the brand type applied by companies from emerging countries on foreign markets in terms of the СОВО is motivated by market motives and strategic motives.

\section{RESEARCH METHODOLOGY}

To answer the research questions, we applied the multi-case-study method (Yin, 2003) and purposeful sampling (Harsh, 2011) intended to capture the diversity of the studied phenomenon and enable the disclosure of repetitive patterns through literal and theoretical replications (Yin, 2003, pp. 48-49). As e.g. Ebeneyamini and Moghadam (2018) emphasise, case study as a qualitative approach is appropriate to answer the 'why' and 'how' research questions. However, contrary to quantitative research, case studies disallow the identification of a phenomenon's frequency or the generalisation of conclusions for the entire population.

To provide the most precise analysis, we limited our study to one product category only: household appliances. The studied firms vary by the degree of their internationalisation (the number of foreign markets and the share of sales on foreign markets in total sales), the COCO/COBO, and the location of their production facilities (Table 1). The firms were identified based on the information obtained from the APPLIA experts, an association of employers in the household appliances industry (Applia, 2018). When selecting firms and interviewees, we followed their availability (operating in Poland, providing 
required data). We analysed the cases of five household appliances companies originating from Poland, Turkey, South Korea, China (formerly Slovenia); countries classified as emerging markets by the MSCI (2018) at the time of the study (October-November 2018). Due to the research questions posted, we selected companies selling products on foreign markets under brands managed by these firms. We chose household appliances' firms as in that industry companies and brands from emerging markets have been playing an increasingly important role, competing with global brands from developed countries. It is reflected in the growing share of firms from e.g. China, South Korea, Poland, and Turkey in the household appliances market and in the growing market shares of their brands in a number of markets, including European ones (e.g. Applia, 2018; Euromonitor International, 2016).

To ensure credibility, we used a triangulation of data that were obtained from 1) primary sources using ca. two-hours semi-structured in-depth interviews in Polish with six Polish-speaking managers of the surveyed companies or their branch offices in Poland and by applying a semi-structured questionnaire with open-ended questions recommended in studies on the COO (Rashid, Barnes, \& Warnaby, 2016), and 2) secondary sources such as industry reports, companies websites, and firm reports (Yin, 2003).

Table 1. General characteristics of the surveyed companies

\begin{tabular}{|l|l|l|l|l|}
\hline \multicolumn{1}{|c|}{ Company } & \multicolumn{1}{|c|}{ COCO/ COBO } & $\begin{array}{c}\text { Share of sales on } \\
\text { foreign markets in } \\
\text { total sales }\end{array}$ & $\begin{array}{c}\text { Number of foreign } \\
\text { markets }\end{array}$ & $\begin{array}{c}\text { Share of sales under } \\
\text { manufacturer/ licensed } \\
\text { brands in total sales }\end{array}$ \\
\hline Amica & Poland / Poland & $65 \%$ & 55 & $100 \%$ \\
\hline LG Electronics & South Korea / South Korea & $92 \%$ & several dozen & $100 \%$ \\
\hline Arçelik & Turkey / Turkey & vast majority & over 100 & $100 \%$ \\
\hline Gorenje $_{j t}$ & China / Slovenia & $95 \%$ & 40 & $100 \%$ \\
\hline Vestel ${ }_{j t}$ & Turkey / Turkey & majority & 149 & about $18 \%-20 \%$ \\
\hline
\end{tabular}

* The Gorenje brand originates in Slovenia (former Yugoslavia), and in 2018 the Chinese Hisense Group acquired control of it. Source: own study.

The interviews transcripts were subjected to content analysis in search for patterns that concern central concepts of the study. As a theoretical framework for the analysis of the types of brands applied by emerging markets' firms in terms of the $\mathrm{COBO}$, we adopt the typologies proposed in the literature, namely:

1. direct or indirect reference to the СОВО vs the neutralisation of the COBO (Aichner, 2014; Hynes, Caemmerer, Martin, \& Masters, 2014; Herstein, Berger, \& Jaffe, 2014), and

2. a) a company acquires an already existing well-known brand,

b) an occidental-style brand created ex nihilo,

c) a brand that already exists in the home country, and

d) a 'local-go-global' brand (Chailan \& Ille, 2015).

In order to identify the motives of applying various brand types in terms of the $\mathrm{COBO}$, we used an inductive approach (Nowell, Norris, \& White, 2017).

\section{RESULTS AND DISCUSSION}

The surveyed emerging markets' firms apply various approaches to the types of brands in terms of the СОВО and the structure of their brand portfolio on the international market (Table 2).

Referring to the previously indicated typology of branding strategies in terms of the СОВО (direct or indirect reference to the СОВО vs the СОВО neutralisation) and the categories of branding strategies applied by the companies from emerging markets indicated by Chailan and Ille (2015), we identified brand types applied by the studied companies in terms of the СОВO and brand use motives as presented in Table 3. 
Table 2. The types of brands in terms of the СОВО and the structure of brand portfolios in foreign markets

\begin{tabular}{|c|c|}
\hline Company & Types of brands in terms of the СОВО \\
\hline \multicolumn{2}{|r|}{ Monobrand portfolio } \\
\hline \begin{tabular}{|l} 
LG \\
Electronics
\end{tabular} & $\begin{array}{l}\text { Occidental-style brand with an international range created by a company: } \\
\text { LG - a global brand first introduced in South Korea and then in foreign markets; the brand name } \\
\text { is an abbreviation of the previous corporate name and is not associated with the COBO, since } 2016 \\
\text { LG SIGNATURE - a sub-brand with a descriptor introduced in English. }\end{array}$ \\
\hline \multicolumn{2}{|r|}{ Multibrand portfolio } \\
\hline Amica & $\begin{array}{l}\text { Occidental-style brands with an international range created by a company: } \\
\text { Amica - created in an occidental-style, brand name suggests Italian origin, first introduced to the } \\
\text { Polish market (1992) and then to Germany, the Czech Republic, Slovakia, Spain, and the UK, among } \\
\text { other places. } \\
\text { Hansa - created ex nihilo in the occidental style, brand name suggests German origin, first intro- } \\
\text { duced on the Russian market (2000), and then in other countries of Eastern and Southern Europe } \\
\text { and in Kazakhstan, Tajikistan, and Uzbekistan. } \\
\text { A foreign brand with an international range acquired by Amica: } \\
\text { Gram - acquired in 2001, with a regional range (Scandinavian countries) and Danish origin, existing } \\
\text { since } 1899 . \\
\text { A foreign brand with a local range acquired by Amica: } \\
\text { CDA - a British brand acquired in 2015, existing since 1991, sold mainly in the UK. }\end{array}$ \\
\hline Arçelik & $\begin{array}{l}\text { 'Local' brand introduced first on the home market and then on foreign markets: } \\
\text { Arçelik - created by Arçelik; brand name associated with Turkish origin because of its spelling, sold } \\
\text { mainly in Turkey and a few neighbouring markets (the brand's website is available only in Turkish). } \\
\text { Occidental-style brand with an international range created by Arçelik: } \\
\text { Beko - created in the occidental-style, with an international range, brand name is not associated } \\
\text { with Turkey, first introduced to the UK, and then to } 130 \text { other foreign markets. } \\
\text { A foreign brand with an international range acquired by Arçelik: } \\
\text { Grundig - a global brand of German origin, existing since 1945. } \\
\text { Blomberg - a global brand of German origin and long tradition (since 1883), sold, among others, } \\
\text { on the German market, in the UK, the USA, Kazakhstan, Azerbaijan, and Taiwan. } \\
\text { Foreign brands with local range acquired by Arçelik: } \\
\text { a) from developed countries: } \\
\text { Elektrabregenz - acquired in } 2002, \text { existing in Austria since 1989, with a German name. } \\
\text { Leisure - acquired in 2002, of British origin and English name, existing for over } 230 \text { years. } \\
\text { Flavel - acquired in 2002, of British origin, existing since 1777, one of the most famous household } \\
\text { appliances brands in the UK and Ireland. } \\
\text { b) originating from emerging or developing markets: } \\
\text { Arctic - local brand acquired in 2002, existing in Romania since 1968, } \\
\text { Dawlance - local brand acquired in 2016, existing in Pakistan since 1980, } \\
\text { Defy - local brand acquired in 2011, existing in South Africa since 1905. }\end{array}$ \\
\hline Gorenje & $\begin{array}{l}\text { A Iocal' brand first introduced on the domestic market and then on foreign markets: } \\
\text { Gorenje - a global brand of Slovenian origin created in 1954, first introduced on the market of } \\
\text { former Yugoslavia and then on foreign markets: in } 1972 \text { in Germany and then in many European } \\
\text { markets, in South America (e.g. Brazil, Chile), and Asia (e.g. China, Vietnam, Thailand). } \\
\text { A foreign brand with an international range acquired by Gorenje: } \\
\text { Asco - acquired in 2010, of Swedish origin, and with a global range. } \\
\text { Foreign brands with an international (regional) range acquired by Gorenje: } \\
\text { a) originating from highly developed countries: } \\
\text { Atag - acquired in 2008, of Dutch origin, sold in the Benelux countries, } \\
\text { Pelgrim - of Dutch origin, existing since } 1920 \text {, sold mainly in the Benelux countries, } \\
\text { Etna - of Dutch origin and more than } 150 \text { years of tradition in the kitchen appliances market, sold } \\
\text { in the Benelux countries, } \\
\text { UPO - of Swedish origin, sold in the Nordic countries, mainly in Finland, } \\
\text { Körting - of German origin, sold in a few countries of Central and South-Eastern Europe, } \\
\text { b) originating from emerging or developing markets: }\end{array}$ \\
\hline
\end{tabular}




\begin{tabular}{|c|c|}
\hline & Mora - of Czech origin, sold mainly in the Czech Republic and Slovakia. \\
\hline Vestel & $\begin{array}{l}\text { Brand introduced first on the domestic market and then on foreign markets: } \\
\text { Vestel - created by Vestel, sold mainly on the home market in Turkey and in a few neighbouring } \\
\text { markets. } \\
\text { Foreign brands with an international range gained by Vestel through a license agreement, e.g.: } \\
\text { Toshiba, Sharp, JVC - global brands of Japanese origin, applied under a license agreement, sold on } \\
\text { the international market in various categories of household appliances, consumer electronics, } \\
\text { Telefunken - a global brand of German origin, gained under a licence agreement in the category } \\
\text { of TV sets, existing since 1903, sold in about } 120 \text { countries. } \\
\text { Foreign brands with an international range acquired by Vestel: } \\
\text { a) originating from developed countries, e.g.: } \\
\text { Vestfrost - acquired in } 2008, \text { with an international range, of Danish origin, existing since 1963, } \\
\text { sold e.g. in Poland, Ukraine, the UK, } \\
\text { Finlux - acquired in 2006, with an international range, of Finnish origin, sold in Germany, Turkey, } \\
\text { the UK, Poland, France, Finland, Norway, Denmark, and Iceland, } \\
\text { Graetz - of German origin, sold in German-speaking countries, } \\
\text { Digihome - sold in the Scandinavian countries, } \\
\text { Foreign brands with a local range acquired by Vestel: } \\
\text { a) originating from developed countries, e.g.: } \\
\text { Servis - British brand acquired in 2011, existing since 1929, } \\
\text { Isis - British brand of TV sets and household appliances. }\end{array}$ \\
\hline
\end{tabular}

Source: own study.

Table 3. Brand types in terms of the COBO applied by the firms from emerging markets and brand use motives

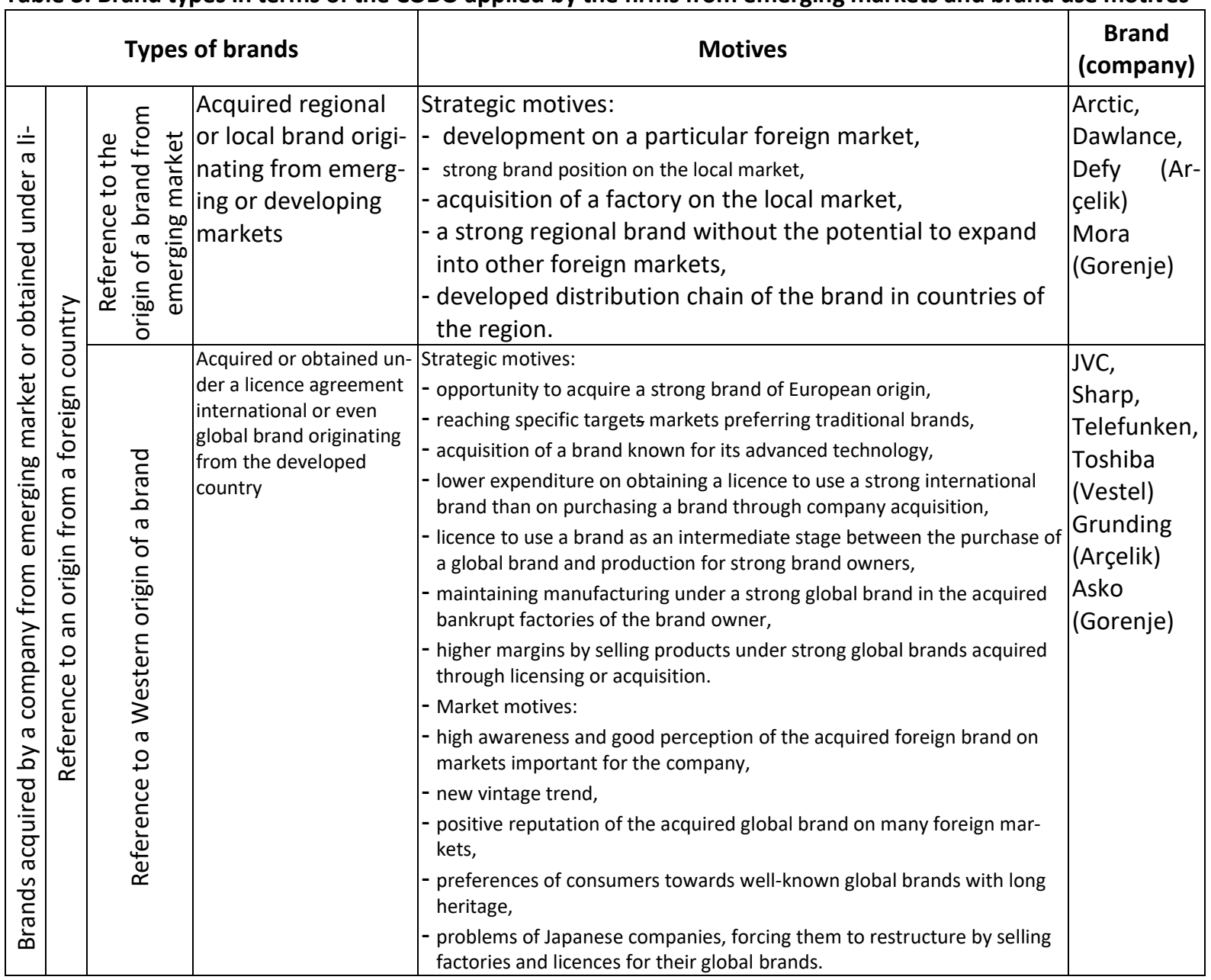




\begin{tabular}{|c|c|c|c|c|c|}
\hline \multicolumn{4}{|c|}{ Types of brands } & Motives & \multirow{2}{*}{\begin{tabular}{|l}
\multicolumn{1}{c}{ Brand } \\
(company) \\
CDA, \\
Gram (Am- \\
ica), \\
Elektrabre- \\
genz, \\
Flavel, \\
Leisure (Ar- \\
çelik)
\end{tabular}} \\
\hline & & & $\begin{array}{l}\text { Acquired regional } \\
\text { or local brand origi- } \\
\text { nating from devel- } \\
\text { oped country }\end{array}$ & $\begin{array}{l}\text { Strategic motives: } \\
\text { - the expansion and strengthening of the firms' position on developed Eu- } \\
\text { ropean markets, } \\
\text { - higher margins on foreign markets when offering products under a } \\
\text { strong brand. } \\
\text { - Market motives: } \\
\text { - high brand awareness and heritage on given foreign markets, } \\
\text { - consumers' preference towards brands with a long tradition in the re- } \\
\text { gion. }\end{array}$ & \\
\hline 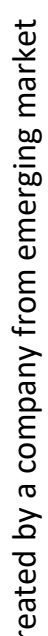 & 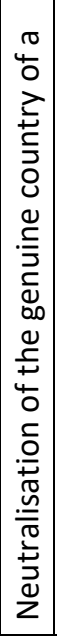 & 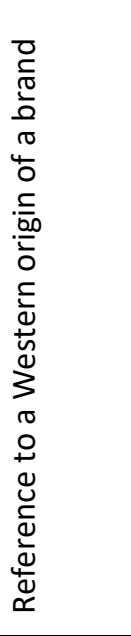 & $\begin{array}{l}\text { Occidental-style } \\
\text { brand created by an } \\
\text { emerging market } \\
\text { firm, suggesting } \\
\text { origin from a devel- } \\
\text { oped country and } \\
\text { created as interna- } \\
\text { tional/global brand }\end{array}$ & $\begin{array}{l}\text { Strategic motives: } \\
\text { - building close relationships with consumers around the world, } \\
\text { - targeting brand to foreign consumers with a name easy to pronounce } \\
\text { and communicate on the global market, } \\
\text { - corporate brand name containing letters that identify the COBO, } \\
\text { - creating a global brand image. } \\
\text { - Market motives: } \\
\text { - positive associations with the characteristics of products originating } \\
\text { from the country with whose language the brand name is associated, } \\
\text { - negative associations by foreign consumers with the genuine COO, } \\
\text { - the perception of German brands on many foreign markets as high-qual- } \\
\text { ity, } \\
\text { - the positive effect of a brand associated with German origin on consum- } \\
\text { ers' purchasing decisions, especially in Eastern and Southern Europe, } \\
\text { - the perception of brands from the country of brand owner's origin as more } \\
\text { advanced thanks to other previously created strong international brands } \\
\text { from that country. }\end{array}$ & \begin{tabular}{|l|} 
Amica, \\
Hansa \\
(Amica) \\
Beko (Arçe- \\
lik) \\
LG (LG Elec- \\
tronics)
\end{tabular} \\
\hline 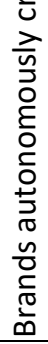 & 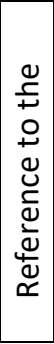 & 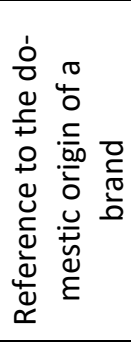 & $\begin{array}{l}\text { 'Local' brand al- } \\
\text { ready existing in the } \\
\text { home country cre- } \\
\text { ated by a company } \\
\text { from an emerging } \\
\text { market and intro- } \\
\text { duced on foreign } \\
\text { markets }\end{array}$ & $\begin{array}{l}\text { Market motives: } \\
\text { - better perception of brands of European origin than brands from China, } \\
\text { - poor perception of China as the COBO in comparison to the European } \\
\text { origin of a brand, } \\
\text { - positive image of the COBO on many foreign markets, especially in Cen- } \\
\text { tral and Eastern Europe, } \\
\text { - the perception of a brand on a given foreign market as a pioneer of a } \\
\text { specific product category. }\end{array}$ & $\begin{array}{l}\text { Gorenje } \\
\text { (Gorenje) } \\
\text { Arçelik (Ar- } \\
\text { çelik) }\end{array}$ \\
\hline
\end{tabular}

Source: own study.

We identified various brand types applied by the studied firms in terms of the COBO, along with strategic and market motives for using these brand types:

1. Referring to the brand origin from a foreign country:

a) Well-known international, and even global, brand from a developed country acquired by an emerging-market firm (e.g. Grundig, Blomberg, Asko) or obtained under a licence agreement usually for at least five to 10 years (e.g. JVC, Sharp, Telefunken, Toshiba), whose use allows users to create positive image of their $\mathrm{COBO}$.

Grundig is an example of a strong brand originating from a developed country (Germany) and acquired by an emerging-market firm (Arçelik, Turkey). This brand for years has been perceived as a global brand, especially in the electronics market. Arçelik started applying the Grunding brand in 2004 but it has recently focused on the development of this brand on the international market, extending it also to household appliances and positioning it as a premium brand of German origin.

The interviewee from Company-Arçelik emphasised that,

Grundig has all the time been a very strong brand in Germany. It is a brand perceived as typically European ... mainly dedicated to such countries as Germany or Scandinavia, because Grundig was also known there ... to focus on more demanding consumers who remember this brand from the past .... [so Grundig was used] to take advantage of a trend now common on the market: the new vintage. 
In turn, Toshiba, Sharp and JVC are examples of strong global brands applied by an emerging market firm (Vestel, Turkey) under a licence agreement. These brands are important for Vestel's international brand portfolio: e.g. on the Polish market about $90 \%$ of sales are products based on licensed brands such as Toshiba (TV sets), Sharp (household appliances), JVC or Hitatchi (TV sets), which are still characterised by the high level of awareness and a very good image among Polish consumers. The rationale for obtaining licences for the use of these brands in the foreign expansion of Vestel is primarily the lower cost of obtaining them under a licence than acquisition (licence fees amounting to approximately a few percent of the value of sales of products labelled with these brands) and positive associations with their СOBO (Germany, Japan).

The interviewee from Company Vestel stated that:

These brands are strong for historical reasons, so using them absolutely matters. If it did not matter, there would be no licence. ... Vestel is not a global company, but buying a global brand is a greater expense. In the case of licenses, we pay percentage but do not buy the brand.... It is much easier to sell a Toshiba TV set than the same one with a Vestel label. ... Japanese companies had started to have problems; they couldn't respond quickly to market changes, so they noticed: why should we have factories, blown costs, people, etc.? ... these licenses are such an intermediate stage between having a brand and manufacturing by order ... often it is a matter of chance, because there is an opportunity, because the customer goes bankrupt.

Moreover, the interviewee indicate such motives for acquiring licence agreement with well-known international brands from developed countries as the acquisition of a brand owner known for advanced technology, preferences of consumers towards well-known global brands with long heritage, and higher margins by selling products under known global brands.

b) Acquiring by an emerging market firm of a strong regional brand (offered in a dozen or so countries of a given region; e.g. Gram) or a local brand (e.g. CDA) originating from developed country. The use of these brands makes it possible to refer to their СОВO. An example of this type of brand is a Danish brand Gram acquired by Amica SA (Poland). An interviewee from Amica explained:

the aim certainly was to expand into Western markets, affluent and offering higher margins, plus the use of the potential of the Gram brand, which was the strongest in refrigeration equipment ... [as] Scandinavian consumers are very conservative, very used to what they have had for years ... [so] it would be a tough fight to make them buy Amica products .... the purchase was all about using the umbrella of familiarity towards Gram. This brand is better known, has a longer heritage, and is positioned higher than Amica.

c) Acquiring by an emerging market firm of a strong regional brand (offered in a dozen or so countries; e.g. Mora) or a local brands (e.g. Arctic) originating from emerging or developing markets. The use of these brands makes it possible to refer to their СОВO and its use in a given region/country.

Arçelik acquired a number of local and regional brands with a long tradition in particular emerging or developing markets such as Arctic (Romania), Defy (South Africa), and Dawlance (Pakistan). According to the interviewee from Arçelik:

Arçelik bought a local brand Arctic several years ago, and we sell in Romania under this brand ... Arçelik has one approach: if it enters a market, it does so to develop and grow. ... if a brand is strong enough, Arçelik does not kill the brand ... in emerging markets such as Pakistan, among others, we have factories that we have taken over. There are very strong local brands.

Among the motives for acquiring strong local or regional brands originating from emerging or developing countries, interviewees indicated the goal to develop on a particular foreign market a distribution chain for the brand in regional countries.

2. Referring to the origin from home country:

a) A local' brand already existing in the home country is created by an emerging market firm and introduced on foreign markets, including neighbouring ones (e.g. Gorenje, Arçelik). These brands 
are created with reference to the positive СОВО image in the countries of foreign expansion, and they emphasise localness in order to reduce the risk perceived by consumers, also with reference to the success of the brand on the home market.

The example of this type of brand is Gorenje (of Slovenian origin), whose name comes from its first headquarters' hometown. The success of Gorenje in the former Eastern Bloc, including Poland, was the result of the positive perception of Slovenia as the СOBO, Gorenje's long tradition, the high level of familiarity, and positive image in these countries; e.g. in Poland this brand first appeared in the 1970s and was the first brand of automatic washing machines. The brand communicates its origin in Slovenia as the member of European Union: 'European products answer to typical Chinese production, which is poorly associated .... Slovenia is the region with the best organised people. This is also reflected in their economic situation. They were the first in Eastern Europe to join the European Union and adopt the euro.'

In turn, Arçelik was the first brand used by the company Arçelik in household appliances market and successfully developed primarily on its home market (Turkey), but it is also exported to several neighbouring countries.

2. The neutralisation of a genuine brand origin by suggesting its foreign origin:

a) Occidental-style brand created by an emerging market firm and applied in foreign expansion - by suggesting origin from a developed country (e.g. Amica, Hansa, LG, Beko) - created as an international or even global brand.

These brands may be introduced first on the home market and, then, on foreign markets (e.g. Amica) or created ex nihilo for the purpose of expansion on foreign markets (e.g. Hansa, Beko). Amica is an 'occidental-style' brand as its brand name is associated with the Italian word amica, which in Latin means 'a friend, friendly.'

As the interviewee from Amica states: 'everything Italian is associated with design .... Our trademark symbolises our commitment to maintaining close relationships with customers around the world .... On the German market, the use of a non-Polish sounding brand name helps.'

Moreover, in Eastern and Southern European and Central Asian markets Amica introduced the Hansa brand created ex nihilo, whose name suggests German origin. This brand was created to expand into Russia and other markets of Eastern and Southern Europe.

The interviewee from Amica stresses the importance of using in the household appliances/consumer electronics industry brands suggesting German origin because of the very positive associations attributed to German products by consumers in these markets: 'Everything that is German clearly supports purchase decisions, so any associations with German origin add a few points in shopping preferences. ... It stems from Russian research: everything originating from Germany is solid and of good quality.'

In turn, the leading international brand of company Arçelik is Beko, created in the occidental style. Beko consists of two initial letters of the two founders' names; it is short, easy to pronounce in many languages, easy to remember, and does not refer to Turkey. As the interviewee emphasises: 'on the European markets, the Beko brand was chosen primarily because it is easy to pronounce and easy as a brand to promote. Arçelik has a specific spelling, it is difficult to pronounce. So, it was necessary to create a brand that would be more international.'

LG is another occidental-style brand, which is the only brand of LG Electronics (South Korea) in the household appliances/consumer electronics industry. The brand was first introduced on the domestic market and then in numerous foreign markets. This brand name is an abbreviation of Lucky Goldstar, which was the former name of the company. The LG brand was created as a global brand, as emphasised on the Polish website of the brand: 'The global dimension, a look into the future, energy, sensitivity to people's needs, and technology are the foundations of LG' (lg.com/pl/o-lg/nasza-marka). Emphasis on the global character emerges from the LG brand, its logo, and the brand slogan. A strong global brand image created by the brand owner seeks to neutralise the effect of its South Korean origin, not to mention the competition from Chinese brands. As the interviewee emphasises: 'Korean companies began to be perceived as more advanced. And it was mainly based on Samsung, which was the first strong brand from Korea, while the second was probably Hyundai. Now, the perception of Korean products is as good that of Japanese products 15-20 years ago.' 
The findings of our study agree with the conclusions of previous studies (e.g. Aichner, 2014; Hynes, Caemmerer, Martin, \& Masters). Moreover, our research confirms the conclusions of Chailan and Ille's (2015) study that one of the brand types applied by emerging markets' firms in terms of the COBO is acquired strong international or even global brand originating from developed country (e.g. Grundig, Blomberg, Asko). However, we found that emerging markets' firms not only acquire well-known global brands with a significant reputation but also obtain them under licences (e.g. JVC, Sharp, Toshiba), which enables referencing the latter's positive СОВО image (e.g. German or Japanese) and reducing costs.

Moreover, our research showed that emerging markets' companies may apply a monobrand portfolio (like LG) or a multibrand portfolio (like the other studied companies), which supports the results of Fan's (2008) study, as the vast majority of studied companies apply multiple brands. Furthermore, emerging markets' companies use a brand whose name can be associated with the language of a country perceived as a COBO (e.g. Amica, Grundig, Hansa) and avoid using brands with names associated with the language of the company's genuine country of origin (e.g. Arçelik), which is consistent with the signalling theory (Magnusson, Haas, \& Zhao, 2008). As for the motives of applying various types of brands in terms of the СОВО, interviewed managers indicated both strategic and market motives. Among the strategic motives, we may indicate lower expenditures on obtaining a licence than on purchasing a brand or its autonomous creation. Among other things, this may result from limited resources of emerging markets' companies or their minor marketing experience on foreign markets (Luo \& Tung, 2007). The market motives we identified are confirmed by many previous studies from the consumer perspective (e.g. Josiassen \& Harzing, 2008). These motives is e.g. positive reputation of acquired global brands originating from developed countries or the ones known on many foreign markets, but also the poor reputation of brands originating from emerging markets.

\section{CONCLUSIONS}

According to our study, companies from emerging markets that operate in the household appliances industry apply various brand types in terms of the СOBO by 1) referring to the brand origin from a foreign country, 2) referring to the brand origin from the home market, and 3) neutralising the COBO effect. Our research shows that companies from emerging markets, which want to refer in their international branding to the image of a developed country, acquire not only global brands but also strong regional brands (sold in several countries of a given region; e.g. Gram) and even local brands (e.g. CDA) from these countries. Moreover, emerging markets' firms acquire well-known regional (e.g. Mora) or local (e.g. Arctic) brands that originate from emerging or developing economies applied locally/regionally, which refer to the positive image of their СОВO.

Furthermore, we found that emerging markets' companies may refer to the origin of the brand from the home country by launching their local' brand, created by the company on the home market and introduced to foreign markets (e.g. Gorenje, Arçelik). This method confirms the conclusions of Chailan and Ille's study (2015). Among the brands applied by the studied firms, our study did not identify one of the brand types listed by Chailan and Ille (2015), namely the new local go global' brands, created as deeply rooted in the local origin. We justify this by the fact that in the case of high involvement products, including household appliances (Seitz, Razzouk, \& Wells, 2010), the impact of the COBO on consumer purchases is higher compared to low involvement products (Dinnie, 2004). Moreover, household appliances are not classified as strongly culture-bound, whose purchase is significantly influenced by the СОВO (Cleveland, Rojas-Méndez, Laroche, \& Papadopoulos, 2016), which explains why references to cultural values are not used in these brands' positioning.

Emerging markets' firms also neutralise the СОВО effect by creating occidental-style brands, whose names suggest they originate from a developed country (e.g. Amica, Hansa, LG, Beko) and are international, even global brands. The study shows that these brands may be created ex nihilo for the purpose of expansion into foreign markets (e.g. Hansa, Beko), as indicated by Chailan and Ille (2015), but they may also be introduced on the home market first, only later to be launched on foreign markets (e.g. Amica). 
Our study shows that emerging markets' firms differ among themselves in types of brands they apply on foreign markets, in terms of the СОВО, and in terms of the structure of their brands' portfolio: from a portfolio consisting of a single brand (LG Electronics) to portfolios that cover several or dozen brands, including international, regional, and local (e.g. Arçelik, Amica SA, Goreenje, Vestel). The South Korean company LG strives to create one strong global brand in Western style, also by intensifying brand promotion in various countries around the world. In turn, the Turkish company Vestel primarily focuses on acquiring many brands - recognised internationally, regionally, or only locally - often by taking advantage of market opportunities. Moreover, there appear different market and strategic motives that determine the application of various brand types in terms of the СOBO.

This study contributes to the existing literature by developing a deeper understanding of the international branding of emerging markets' companies in terms of the COBO and the structure of the brands' portfolios used by these firms on the international market. This is particularly important as the research so far focused primarily on companies and brands from developed countries, while a few studies referring to emerging markets mainly focused on Asian companies (Xie \& Boggs, 2006).

One of the main limitations of our article is that among companies analysed in our multiple-case study, there appear firms from only four emerging markets: Poland, Turkey, Slovenia (acquired by a Chinese company), and South Korea. Moreover, only Polish managers took part in the study, although they had experience not only on the Polish market but also on the international one. Furthermore, our study is limited to the household appliances industry, which is quite specific, among other things, due to intense international competition, geographical scope, and global value chains. Future research would benefit from including firms from other emerging markets and industries, also meaning managers from various countries who represent different approaches to the studied phenomena. Scholars should also consider conducting quantitative research on the relations between international branding strategy in terms of the COBO applied by companies from emerging markets and brand/company performance.

\section{REFERENCES}

Aichner, T. (2014). Country-of-origin marketing: a list of typical strategies with examples. Journal of Brand Management, 21(1), 81-93. https://doi.org/10.1057/bm.2013.24

Applia. (2018). Raport AGD 2018. Retrieved from http://applia.pl/wpcontent/uploads/2019/01/APPLI A.PL_raport-AGD-2018.pdf on September 21, 2020.

Aruan, D.T.H., Crouch, R., \& Quester, P. (2018). Relative importance of country of service delivery, country of person and country of brand in hybrid service evaluation: a conjoint analysis approach. Journal of Product and Brand Management, 27(7), 819-831. https://doi.org/10.1108/JPBM-10-2017-1608

Brodie, R.J., \& Benson-Rea, M. (2016). Country of origin branding: an integrative perspective. Journal of Product and Brand Management, 25(4), 322-336. https://doi.org/10.1108/JPBM-04-2016-1138

Chailan, C., \& Ille, F. (2015). Branding from emerging countries: how to compete internationally?. Critical Perspectives on International Business, 11(1), 54-71. https://doi.org/10.1108/cpoib-11-2012-0055

Chao, P., Samiee, S., \& Yip, L.S. (2004). Guest editorial: international marketing in the Asia Pacific region. International Marketing Review, 21(3), 243-246. https://doi.org/10.1108/02651330410539594

Chu, P.Y., Chen, C.Y., Chang, C.C., \& Wang, T.T. (2010). Countering negative country-of-origin effects: the role of evaluation mode. European Journal of Marketing, 44(7/8), 1055-1076. https://doi.org/10.1108/03090561011047526

Cleveland, M., Rojas-Méndez, J., Laroche., M., \& Papadopoulos, N. (2016). Identity, culture, dispositions and behavior: A cross-national examination of globalization and culture change. Journal of Business Research, 69(3), 1090-1102. https://doi.org/10.1016/j.jbusres.2015.08.025

Coffey, S., \& Kabadayi, S. (2020). Consumers` purchase intentions of bi-national products: effects of country-ofbrand, country-of-manufacture, and trusting beliefs. Journal of Global Marketing, 33(1), 18-33. https://doi.org/10.1080/08911762.2019.1579398

Dinnie, K. (2004). Country-of-origin 1965-2004: a literature review. Journal of Customer Behaviour, 3(2), 165-213. https://doi.org/10.1362/1475392041829537 
Ebeneyamini, S., \& Moghadam, M.R.S. (2018). Toward developing a framework for conducting case study research. International Journal od Qualitative Methods, 17, 1-11. https://doi.org/10.1177/1609406918817954

Erdem, T., Swait, J., \& Valenzuela, A. (2006). Brands as signals: a cross-country validation study. Journal of Marketing, 70, 34-49. https://doi.org/10.1509/jmkg.70.1.034.qxd

Erdoğmuş, I., Bodur, M., \& Yilmaz, C. (2010). International strategies of emerging market firms. European Journal of Marketing, 44(9/10), 1410-1436. https://doi.org/10.1108/03090561011062907

Euromonitor International. (2016). Emerging countries lead consumer appliances production volume. Retrieved from https://blog.euromonitor.com/emerging-countries-lead-consumer-appliances-production-volume/ on September 22, 2020.

Fan, Y. (2008). Country of origin, branding strategy and internationalisation: the case of Chinese piano companies. Journal of Chinese Economic and Business Studies, 6(3), 303-319. https://doi.org/10.1080/14765280802283618

Guzmán, F., \& Paswan, A.K. (2002). Cultural brands from emerging markets: brand image across host and home countries. Journal of International Marketing, 17(3), 71-86. https://doi.org/10.1509/jimk.17.3.71

Han, C., \& Terpstra, V. (1988). Country-of-origin effects for uni-national and bi-national products. Journal of International Business Studies, 19(2), 235-255. https://doi.org/10.1057/palgrave.jibs.8490379

Harsh, S. (2011). Purposeful sampling in qualitative research synthesis. Qualitative Research Journal, 11(2), 63-75. https://doi.org/10.3316/QRJ1102063

Herstein, R., Berger, R., \& Jaffe, E.D. (2014). How companies from developing and emerging countries can leverage their brand equity in terms of place branding. Competitiveness Review, 24(4), $293-305$. https://doi.org/10.1057/palgrave.pb.6000050

Huang, H.Y., \& Hsieh, M.H. (2011). An international branding strategy based on a case study of a Taiwanese firm. Marketing Intelligence and Planning, 29(6), 611-623. https://doi.org/10.1108/02634501111166120

Hynes, N., Caemmerer, B., Martin, E., \& Masters, E. (2014). Use, abuse or contribute!: A framework for classifying how companies engage with country image. International Marketing Review, 31(1), 79-97. https://doi.org/10.1108/IMR-12-2012-0206

Ille, F.R., \& Chailan, C. (2011). Improving global competitiveness with branding strategy. Cases of Chinese and emerging countries' firms. Journal of Technology Management in China, 6(1), 84-96. https://doi.org/10.1108/17468771111105677

Insch, G.S., \& McBride, J.B. (1998). Decomposing the COO construct: an empirical test of country of design, country of parts and country of assembly. Journal of International Consumer Marketing, 10(4), 69-91. https://doi.org/10.1300/J046v10n04_05

Josiassen, A., \& Harzing, A.-W. (2008). Descending from the ivory tower: Reflections on the relevance and future of country of-origin research. European Management Review, 5(4), 264-270. https://doi.org/10.1057/emr.2008.19

Karimov, F., \& El-Murad, J. (2018). Does country-of-origin matter in the era of globalisation? Evidence from cross sectional data in Uzbekistan. International Journal of Retail and Distribution Management, 47(3), 262-277. https://doi.org/10.1108/IJRDM-06-2017-0129

Kazlauskaitè, R., Autio, E., Šarapovas, T., Abramavičius, Š., \& Gelbūdam, M. (2015). The speed and extent of new venture internationalisation in the emerging economy context. Entrepreneurial Business and Economics Review, 3(2), 41-52. https://doi.org/10.15678/EBER.2015.030204

Kim, Y. (2006). Do South Korean companies need to obscura their country-of-origin image? A case of Samsung. Corporate Communications: An International Journal, 11(2), 126-137. https://doi.org/10.1108/13563280610661660

Kim, N., Chun, E., \& Ko, E. (2017). A closer look at Seoul, New York, and Paris fashion collection. International Marketing Review, 34(2), 254-271. https://doi.org/10.1108/IMR-03-2015-0071

Kirmani, A., \& Rao, A.R. (2000). No pain, no gain: a critical review of the literature in signaling unobservable product quality. Journal of Marketing, 64, 66-79. https://doi.org/10.1509/jmkg.64.2.66.18000

Lee, S. (2019). When does the developing country brand name alleviate the brand origin effect? Interplay of brand name and brand origin. International Journal of Emerging Markets, 15(2), 387-402. https://doi.org/10.1108/IJOEM-10-2018-0543 
Luo, Y., \& Tung, R.L. (2007). International expansion of emerging market enterprises: a springboard perspective. Management International Review, 38, 481-498. https://doi.org/10.1057/palgrave.jibs.8400275

Magnusson, P., Haas, S.M., \& Zhao, H. (2008). A branding strategy for emerging market firms entering developed markets. Joumal of Intemational Consumer Marketing, 20(3-4), 95-107. https://doi.org/10.1080/08961530802129490

Magnusson, P., Westjohn, S.A., \& Zdravkovic, S. (2011). What? I thought Samsung was Japanese: accurate or not, perceived country of origin matters. International Marketing Review, 28(5), 454-472. https://doi.org/10.1108/02651331111167589

McKinsey Global Institute. (2018). Outperformers: high-growth emerging economies and the companies that propel them. Retrieved from

https://www.mckinsey.com/ /media/McKinsey/Featured\%20Insights/Innovation/Outperformers\%20High\%20growth\%20emerging\%20economies\%20and\%20the\%20companies\%20that\%20propel\%20them/MGI-Outperformers-Full-report-Sep-2018.pdf on September 16, 2020.

MSCI. (2018). MSCl Annual Market Classification Review. Retrieved from https://www.msci. com/market-classification on September 16, 2020.

Nagashima, A. (1970). A comparison of Japanese and U.S. attitudes toward foreign products. Journal of Marketing, 34(1), 68-74. https://doi.org/10.1177/002224297003400115

Nowell, L.S., Norris, J.M., \& White, D.E. (2017). Thematic analysis: striving to meet the trustworthiness criteria. International Journal of Qualitative Methods, 16, 1-13. https://doi.org/10.1177/1609406917733847

Ozsomer, A., \& Cavusgil, T. (1991). Country-of-origin effects on product evaluations: A sequel to Bilkey and Nes review. In M.C., Gilly (Ed.). Proceedings of American Marketing Association (pp. 269-277).

Pillania, R.K. (2009). Multinationals and emerging markets. Business Strategy Series, 10(2), 100-103. https://doi.org/10.1108/17515630910942232

Rashid, A., Barnes, L., \& Warnaby, G. (2016). Management perspectives on country of origin. Journal of Fashion Marketing and Management, 20(2), 230-244. https://doi.org/10.1108/JFMM-07-2015-0056

Samiee, S., Shimp, T.A., \& Sharma, S. (2005). Brand origin recognition accuracy: its antecedents and consumers' cognitive limitations. Journal of International Business Studies, 36(4), 379-397. https://doi.org/10.1057/palgrave.jibs. 8400145

Thakor, M.V., \& Kohli, C.S. (1996). Brand origin: conceptualization and review. Journal of Consumer Marketing, 13(3), 27-42. https://doi.org/10.1108/07363769610147929

Thakor, M.V., \& Lavack, A.M. (2003). Effect of perceived brand origin association on consumer perceptions of quality. Journal of Product and Brand Management, 12(6), 394-407. https://doi.org/10.1108/10610420310498821

Xie, H.Y., \& Boggs, D.J. (2006). Corporate branding versus product branding in emerging markets - a conceptual framework. Marketing Intelligence and Planning, 24(4), 347-364. https://doi.org/10.1108/02634500610672099

Yin, R.K. (2003). Case study research: Design and methods (3rd ed.). SAGE.

Zhou, L., Yang, Z., \& Hui, M.K. (2010). Non-local or local brands? A multi-level investigation into confidence in brand origin identification and its strategic implications. Journal of the Academy of Marketing Science, 38(2), 202-218. https://doi.org/10.1007/s11747-009-0153-1

Seitz, V., Razzouk, N., \& Michael Wells, D. (2010). The importance of brand equity on purchasing consumer durables: an analysis of home air-conditioning systems. Journal of Consumer Marketing, 27(3), 236-242. https://doi.org/10.1108/07363761011038301 


\section{Authors}

The contribution share of authors is equal and amounted to $50 \%$ for each of them.

\section{Marzanna K. Witek-Hajduk}

Associate Professor at the Institute of International Management and Marketing, SGH Warsaw School of Economics. Deputy Dean of the SGH Doctoral School. Chair of the International Busi-ness Department. Her research interests include firm internationalisation, international brand-ing, retailer brands, digital marketing, and business models.

Correspondence to: Prof. Marzanna K. Witek-Hajduk, PhD, SGH Warsaw School of Economics, Al. Niepodległości 162, 02-554 Warsaw, Poland, e-mail: mwitek@sgh.waw.pl

ORCID (1) http://orcid.org/0000-0003-3670-3587

\section{Anna Grudecka}

Assistant Professor at the Institute of International Management and Marketing, SGH Warsaw School of Economics. Her research interests focus on consumer behaviour, retailers' brands, international branding, and firm internationalisation.

Correspondence to: Dr. Anna Grudecka, SGH Warsaw School of Economics, Al. Niepodległości 162, 02-554 War-saw, Poland, e-mail: agrude@sgh.waw.pl

ORCID (1) http://orcid.org/0000-0003-4349-3813

\section{Acknowledgements and Financial Disclosure}

The research was funded by the National Science Centre conferred on the basis of the decision No. UMO2017/25/B/HS4/00372.

\section{Conflict of Interest}

The authors declare that the research was conducted in the absence of any commercial or financial relationships that could be construed as a potential conflict of interest.

\section{Copyright and License}

This article is published under the terms of the Creative Commons

Attribution - NoDerivs (CC BY-ND 4.0) License

http://creativecommons.org/licenses/by-nd/4.0/ 